\title{
Hygroscopic behaviour of cassava flour from dry and water groups
}

\section{Comportamento higroscópico das farinhas de mandioca tipos seca e d'água}

\author{
Renan Campos Chisté ${ }^{\text {Jonnahta Monteiro Cardoso }}{ }^{\text {II }}$ \\ Diego Aires da Silva ${ }^{I I I}$ Rosinelson da Silva Pena ${ }^{I V}$
}

\section{ABSTRACT}

Cassava flour from dry and water groups are important starch products widely consumed in the Amazonian region of Brazil. In this study, the moisture sorption isotherms of cassava flour from dry and water groups were obtained in the water activity $\left(a_{w}\right)$ range from 0.09 to 0.94 (dry group) and 0.07 to 0.93 (water group) at $25^{\circ} \mathrm{C}$ and the applicability of eight mathematical models in data prediction was evaluated. Both cassava flour from dry and water groups exhibited type II isotherms (sigmoid) and the hysteresis effect between adsorption and desorption isotherms was shown almost over the entire range of $a_{w}$. The moisture of cassava flour from dry and water groups should not exceed $11.3 \mathrm{~g} \mathrm{H} \mathrm{H}_{2} 100 \mathrm{~g}^{-1}$ $\left(a_{w}=0.6\right)$ to ensure the theoretical microbiological stability and the monolayer moisture value (9.0 and $7.9 \mathrm{~g} \mathrm{H}_{2} \mathrm{O} 100 \mathrm{~g}^{-1}$, respectively) indicated the level of moisture content to be reached during the drying process to avoid unnecessary power consumption. Finally, the data fit showed that the mathematical model of GAB were able to predict efficiently the sorption isotherms of both cassava flour from dry and water group at the entire $a_{w}$ range.

Key words: Manihot esculenta, sorption isotherms, mathematical models, starchy product, water activity.

\section{RESUMO}

As farinhas de mandioca do grupo seca e do grupo d'água são produtos amiláceos amplamente consumidos na região amazônica do Brasil. Neste estudo, as isotermas de adsorção e dessorção de umidade foram obtidas para ambos os produtos a $25^{\circ} \mathrm{C}$, na faixa de atividade de água (a) de 0,09 a 0,94 (tipo seca) e 0,07 a 0,93 (tipo d'água). Foi avaliada a aplicabilidade de oito modelos matemáticos na predição das isotermas de sorção. Tanto a farinha tipo seca quanto a farinha tipo d'água apresentaram isotermas tipo II (sigmoide) e um efeito de histerese entre as isotermas de adsorção e dessorção, que se estendeu em toda a faixa de $a$. Para que a estabilidade microbiológica teórica seja assegurada, a umidade em ambas as farinhas de mandioca não pode alcançar valores superiores a $11,3 \mathrm{~g} \mathrm{H}_{2} \mathrm{O} 100 \mathrm{~g}^{-1}\left(a_{w}=0,6\right)$. $O$ valor da monocamada das farinhas seca e d'água (9,0 e 7,9 $\mathrm{g}$ $\mathrm{H}_{2} \mathrm{O} 100 \mathrm{~g}^{-1}$, respectivamente) indicou que esses niveis de umidade não devem ser atingidos durante a secagem dos produtos, para evitar gasto desnecessário de energia. Finalmente, o modelo de GAB mostrou-se altamente eficiente na predição das isotermas de sorção de ambos os produtos, em toda a faixa de $a_{w}$ estudada.

Palavras-chave: Manihot esculenta, isotermas de sorção, modelos matemáticos, produto amiláceo, atividade de água.

\section{INTRODUCTION}

Cassava is the main carbohydrate source for a significant portion of the population in Brazilian Amazonian region, especially in Pará State, with high economic importance to producers and small cities mainly due to the production of cassava flour. Cassava flour from dry and water groups are starch products widely consumed in Amazonian region, which is obtained after drying cassava roots (Manihot esculenta Crantz). The difference between the production of cassava flour from dry group and cassava flour from water group is related to the fermentation process of cassava roots for producing the water group flour (MAPA; 2011). The

'Departamento de Ciências Químicas, Faculdade de Farmácia, Universidade do Porto, Porto, Portugal.

IIPrograma de Pós-graduação em Ciência e Tecnologia de Alimentos, Universidade Federal do Pará (UFPA), Belém, PA, Brasil.

IIIDepartamento de Tecnologia de Alimentos, Centro de Ciências Naturais e Tecnologia, Universidade do Estado do Pará (UEPA), Belém, PA, Brasil.

${ }^{\text {IV }}$ Faculdade de Engenharia de Alimentos, Instituto de Tecnologia, UFPA, 66075-900, Belém, PA, Brasil. E-mail: rspena@ufpa.br. Corresponding author. 
fermentation step of roots is performed during four days in water tanks, providing a peculiar acid taste to the cassava flour from water group and this sensory characteristic was reported as its main attractive (CHISTÉ \& COHEN, 2011).

The data prediction of sorption isotherms are extremely important, since drying is the main process to obtain different kind of flours and is the most widely used method for the food preservation due to the reduction of water activity $\left(a_{w}\right)$. This approach leads to the efficient modelling of drying processes, the design and optimization of drying equipment, the prediction of shelf-life, the moisture changes, which may occur during storage, and also to select appropriate packaging material (KULCHAN et al., 2010).

The water sorption data for cassava starch (MISHRA \& RAI, 2006; PERDOMO et al., 2009; COVA et al., 2010; SOUZA et al., 2013) and cassava-flour-based baked product (KULCHAN et al., 2010) were described in the literature. In addition, this research also reported the hygroscopic behaviour of tapioca flour (CHISTÉ et al., 2012), another different kind of cassava product, which is produced with starch of high purity degree extracted from cassava roots.

Thus, considering the importance of cassava products to people who lives in Brazilian Amazonian region, the hygroscopic behaviour of cassava flour from both dry and water groups at storage temperature $\left(25^{\circ} \mathrm{C}\right)$ will be reported here for the first time. Furthermore, the sorption isotherms of cassava flour were obtained and the applicability of mathematical models in data prediction for adsorption and desorption moisture was also evaluated.

\section{MATERIAL AND METHODS}

Samples

The cassava flour from dry and water groups (1 kg each) was acquired in bulk at the local open-air markets in Belém, Pará, Brazil (Latitude $01^{\circ} 27^{\prime} 21^{\prime \prime} \mathrm{S}$ and Longitude 48 $\left.30^{\prime} 16^{\prime \prime} \mathrm{W}\right)$. The samples were ground in a food processor and homogenized. A sample of each cassava flour was evaluated.

\section{Proximate composition}

The recommended methods of the Association of Official Analytical Chemists (AOAC, 1997) were adopted to determine the moisture, ashes, total lipids, total proteins (conversion factor of 5.75 from total nitrogen to total protein), reducing sugars, total sugars and starch contents. All the experiments of proximate composition were performed in triplicate

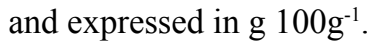

Sorption isotherms and determination of monolayer moisture content

The hygroscopic properties of cassava flour from dry and water groups were obtained from the adsorption and desorption isotherms at $25^{\circ} \mathrm{C}$, according to the procedure described by SOUZA et al. (2013). The sorption isotherms were graphically plotted considering the moisture content versus $\mathrm{a}_{\mathrm{w}}$ of each measurement using Microsoft Office Excel 2003 and Statistica 7.1 softwares. The monolayer moisture content $\left(\mathrm{m}_{\mathrm{o}}\right)$ was calculated using the BET linear equation (Equation 1), which was applied in the linear region of the isotherms range from 0.09 to 0.40 (dry group) and 0.07 to 0.35 (water group) of $\mathrm{a}_{\mathrm{w}}$. $\frac{\mathrm{a}_{\mathrm{w}}}{\left(1-\mathrm{a}_{\mathrm{w}}\right) \mathrm{m}}=\frac{1}{\mathrm{~m}_{\mathrm{o}} \cdot \mathrm{C}}+\frac{(\mathrm{C}-1)}{\mathrm{m}_{\mathrm{o}} \cdot \mathrm{C}} \cdot \mathrm{a}_{\mathrm{w}}$

where, $\mathrm{m}=$ moisture content $\left(\mathrm{g} 100 \mathrm{~g}^{-1}\right.$ dry basis d.b.); $\mathrm{a}_{\mathrm{w}}=$ water activity; $\mathrm{m}_{\mathrm{o}}=$ monolayer moisture content ( $\mathrm{g} 100 \mathrm{~g}^{-1} \mathrm{~d} . \mathrm{b}$.); and $\mathrm{C}=$ constant related to the sorption heat.

\section{Mathematical modelling of sorption isotherms}

Eight mathematical models presented in table 1 were fitted to the isotherms by the nonlinear regression using the Statistica 7.1 software. Mean relative deviation modulus $(\mathrm{P})$ and coefficient of determination $\left(\mathrm{R}^{2}\right)$ were used to compare the fit precision of the sorption models and the LevenbergMarquardt method was used in the non-linear regression procedure $(\mathrm{P}<0.05)$. The $\mathrm{P}$ values lower than $10 \%$ were adopted as an indicative of a good fit for practical purposes (PENG et al., 2007).

\section{RESULTS AND DISCUSSION}

Proximate composition of cassava flour from dry and water groups

The cassava flour from dry and water groups used to obtain the sorption isotherms presented starch as the major component $(76.57 \pm 1.72$ and $68.32 \pm 1.68 \mathrm{~g}$ $100 \mathrm{~g}^{-1}$, respectively, wet basis - w.b.) (Table 2). These values were in the same range or slightly superior than that reported for cassava flour from dry (67.67-79.59g

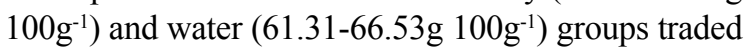
in ten different markets in Belém (Brazil) (CHISTÉ et al., 2006; CHISTÉ \& COHEN, 2010). In addition, the other chemical constituents of these kinds of cassava flour (Table 2) were determined to obtain an overview 
Table 1 - Mathematical models used to fit the sorption isotherms of cassava flour from dry and water groups.

\begin{tabular}{|c|c|c|}
\hline Models & Mathematical equations & Reference \\
\hline Halsey & $\mathrm{m}=\left[\frac{-\mathrm{a}}{\ln \mathrm{a}_{\mathrm{w}}}\right]^{\frac{1}{\mathrm{~b}}}$ & (CHIRIFE \& IGLESIAS, 1978) \\
\hline Handerson & $\mathrm{m}=\left[\frac{-\ln \left(1-\mathrm{a}_{\mathrm{w}}\right)}{\mathrm{a}}\right]^{\frac{1}{\mathrm{~b}}}$ & (CHIRIFE \& IGLESIAS, 1978) \\
\hline Kuhn & $\mathrm{m}=-\frac{\mathrm{a}}{\ln \mathrm{a}_{\mathrm{w}}}+\mathrm{b}$ & (CHIRIFE \& IGLESIAS, 1978) \\
\hline Mizrahi & $a_{w}=\frac{a+m}{b+m}$ & (CHIRIFE \& IGLESIAS, 1978) \\
\hline Oswin & $\mathrm{m}=\mathrm{a}\left[\frac{\mathrm{a}_{\mathrm{w}}}{1-\mathrm{a}_{\mathrm{w}}}\right]^{\mathrm{b}}$ & (CHIRIFE \& IGLESIAS, 1978) \\
\hline Smith & $\mathrm{m}=\mathrm{a}-\mathrm{b} \cdot \ln \left(1-\mathrm{a}_{\mathrm{w}}\right)$ & (CHIRIFE \& IGLESIAS, 1978) \\
\hline BET & $\mathrm{m}=\frac{\mathrm{m}_{\mathrm{o}} \cdot \mathrm{c} \cdot \mathrm{a}_{\mathrm{w}}}{1-\mathrm{a}_{\mathrm{w}}} \cdot\left(\frac{1-(\mathrm{n}+1) \cdot \mathrm{a}_{\mathrm{w}}^{\mathrm{n}}+\mathrm{n} \cdot \mathrm{a}_{\mathrm{w}}^{\mathrm{n}+1}}{1-(1-\mathrm{c}) \cdot \mathrm{a}_{\mathrm{w}}-\mathrm{c} \cdot \mathrm{a}_{\mathrm{w}}^{\mathrm{n}+1}}\right)$ & (FIGUEIRA et al., 2004) \\
\hline GAB & $\mathrm{m}=\frac{\mathrm{m}_{\mathrm{o}} \cdot \mathrm{c} \cdot \mathrm{k} \cdot \mathrm{a}_{\mathrm{w}}}{\left[\left(1-\mathrm{k} \cdot \mathrm{a}_{\mathrm{w}}\right) \cdot\left(1+(\mathrm{c}-1) \cdot \mathrm{k} \cdot \mathrm{a}_{\mathrm{w}}\right)\right]}$ & (MAROULIS et al., 1988) \\
\hline
\end{tabular}

$\mathrm{m}=$ moisture content ( $\mathrm{g} 100 \mathrm{~g}^{-1}$ d.b.) $\mathrm{a}_{\mathrm{w}}=$ water activity; $\mathrm{a}, \mathrm{b}, \mathrm{m}_{\mathrm{o}}, \mathrm{k}$ and $\mathrm{c}$ terms are the parameters to be estimated by fitting.

about the chemical composition, all in accordance with the previous values reported by our research group (CHISTÉ et al., 2006; CHISTÉ et al., 2007; CHISTÉ \& COHEN, 2010; CHISTÉ \& COHEN, 2011). However, only the starch content of cassava flour from dry group ( $84 \pm 2 \%$, calculated in dry basis - d.b.) was in agreement with the Brazilian law (MAPA, 2011), that requires at least $80 \%$ of starch content and was classified as type 2 . The starch content of the cassava flour from water group ( $74 \pm 2 \%$ d.b.) did not follow the same requirements.

Table 2 - Proximate composition and water activity of cassava flour from dry and water groups.

\begin{tabular}{|c|c|c|}
\hline & \multicolumn{2}{|c|}{----------Cassava flour----------- } \\
\hline & Dry group & Water group \\
\hline Moisture $\left({\left.\mathrm{g} 100 \mathrm{~g}^{-1}\right)}\right.$ & $9.17 \pm 0.02$ & $8.28 \pm 0.07$ \\
\hline Ashes $\left(g_{\left.100 g^{-1}\right)}\right.$ & $0.83 \pm 0.01$ & $0.75 \pm 0.01$ \\
\hline Total lipids (g 100 $\left.\mathrm{g}^{-1}\right)$ & $0.26 \pm 0.06$ & $1.04 \pm 0.05$ \\
\hline 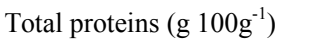 & $0.52 \pm<0.01$ & $1.10 \pm<0.01$ \\
\hline Reducing sugars $\left({\left.\mathrm{g} 100 \mathrm{~g}^{-1}\right)}^{-}\right.$ & $0.51 \pm<0.01$ & $0.34 \pm 0.02$ \\
\hline Total sugars $\left(\mathrm{g}_{\left.100 \mathrm{~g}^{-1}\right)}\right.$ & $1.10 \pm 0.02$ & $0.42 \pm 0.01$ \\
\hline $\operatorname{Starch}\left({\left.\mathrm{g} 100 \mathrm{~g}^{-1}\right)}^{-1}\right.$ & $76.57 \pm 1.72$ & $68.32 \pm 1.68$ \\
\hline Water activity $\left(a_{w}\right)$ & $0.53 \pm<0.01$ & $0.45 \pm 0.01$ \\
\hline
\end{tabular}

Sorption isotherms of cassava flour from dry and water groups

The sorption isotherms at $25^{\circ} \mathrm{C}$ of cassava flour from both groups (Figure 1a and 2a) were classified as a typical sigmoid (type II). The same behaviour was reported for other cassava products (MISHRA \& RAI, 2006; PERDOMO et al., 2009; CHISTÉ et al., 2012).

Considering that water molecules are strongly bound to hydrophilic biopolymers, such as proteins and polysaccharides, the number of sites that strongly bind water molecules must be less in the protein-rich substrate than in the carbohydrate rich substrate. As a result, starchy foods, such as cassava flour, show more Langmuir-like type II isotherms, while the protein-rich foods indicate more solution-like type II isotherms (YANNIOTIS \& BLAHOVEC, 2009).

Hysteresis loop between adsorption and desorption isotherms exhibited consistent characteristics with the type-H3 hysteresis loop, according to IUPAC classification (SING, 1982) and was observed almost over the entire range of $a_{w}$ for both cassava flour (Figure 1a and 2a); whereas, a more pronounced hysteresis effect was observed for cassava flour from dry group. According to CAURIE 


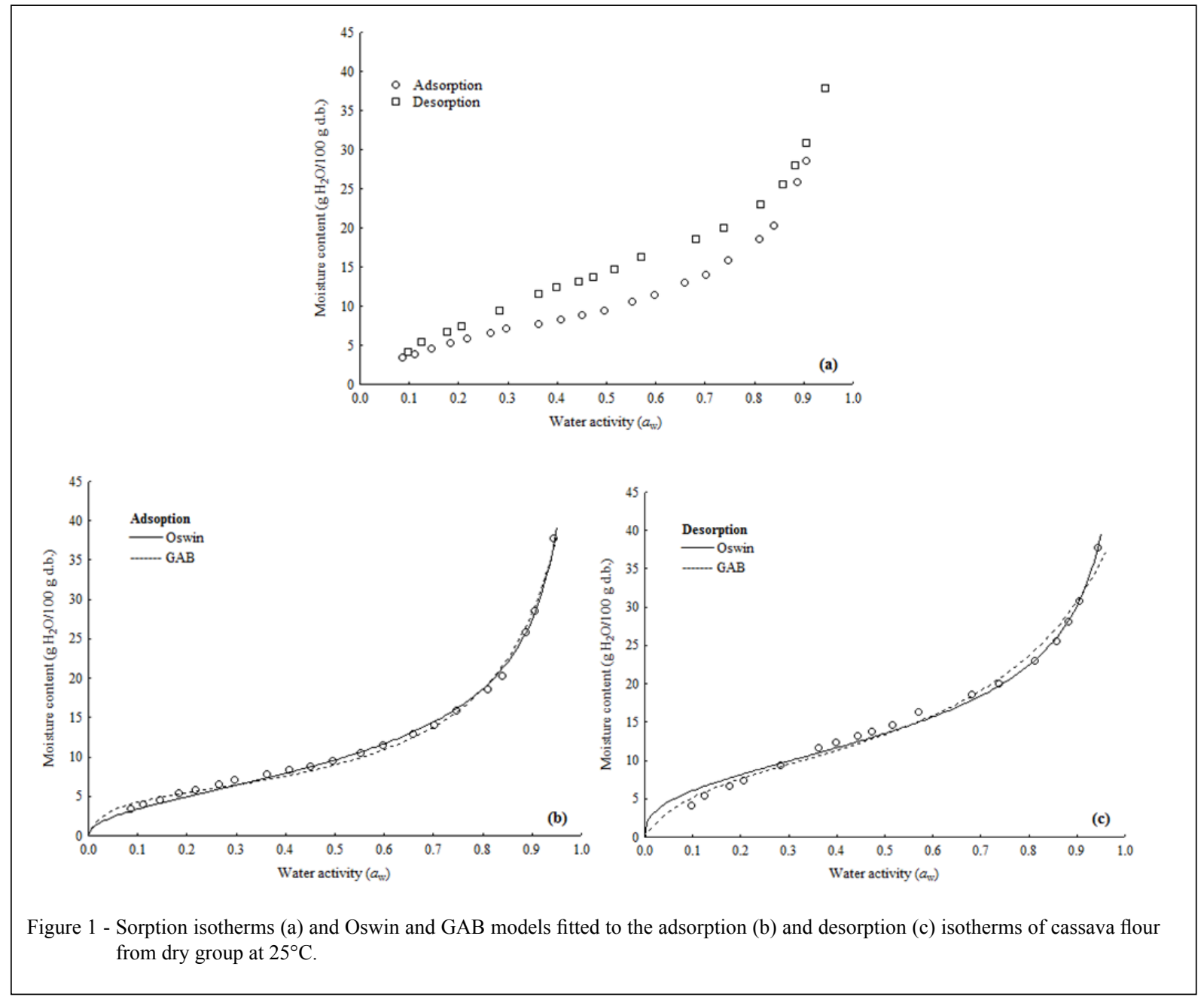

(2007), a decrease in the hysteresis loop or its complete absence has been related to greater product stability during storage.

Considering that the theoretical microbiological stability can be ensured at $\mathrm{a}_{\mathrm{w}}<0.6$ (SCOTT, 1957), the moisture content of cassava flour from dry group and from water group should not be higher than $11.3 \mathrm{~g} \mathrm{H}_{2} \mathrm{O} 100 \mathrm{~g}^{-1}$ d.b (for both products) during storage conditions at $25^{\circ} \mathrm{C}$. Similar results were found for tapioca flour $\left(10.1 \mathrm{~g} \mathrm{H}_{2} \mathrm{O} 100 \mathrm{~g}^{-1}\right.$ d.b.) (CHISTÉ et al., 2012).

The desorption monolayer moisture contents of $9.0 \mathrm{~g} \mathrm{H}_{2} \mathrm{O} 100 \mathrm{~g}^{-1}$ d.b. (cassava flour from dry group) and $7.9 \mathrm{~g} \mathrm{H}_{2} \mathrm{O} 100 \mathrm{~g}^{-1}$ d.b. (cassava flour from water group) indicated the level of moisture contents to be reached during the drying process to avoid unnecessary power consumption. Since, the chemical reactions that depend on solvation are also expected to be slow in the monolayer region (RAO et al., 2006), the $a_{w}$ of both products is lower than 0.30 in this moisture levels and the microbiological stability will be highly ensured. These values were superior than that reported for tapioca flour $\left(4.9 \mathrm{~g} \mathrm{H}_{2} \mathrm{O} 100 \mathrm{~g}^{-1}\right.$ d.b.) (CHISTÉ et al., 2012).

Modelling of sorption isotherms

For adsorption, all the tested models displayed suitability for predicting the isotherm for both products (Table 3 ) with $\mathrm{R}^{2}$ values ranging from 0.94 to 0.99 . However, the lowest $\mathrm{P}$ values (lower than $10 \%$ ) for cassava flour from dry group were observed for the models of Oswin $(4.5 \%)$, Halsey (5.6\%), GAB (5.7\%) and Smith (8.4\%), and for cassava flour from water group, only Halsey, GAB and BET exhibited $\mathrm{P}$ values lower than $10 \%$ (3.4\%, $5.1 \%$ and $9.6 \%$, respectively). These models were also reported to be suitable to fit the adsorption 


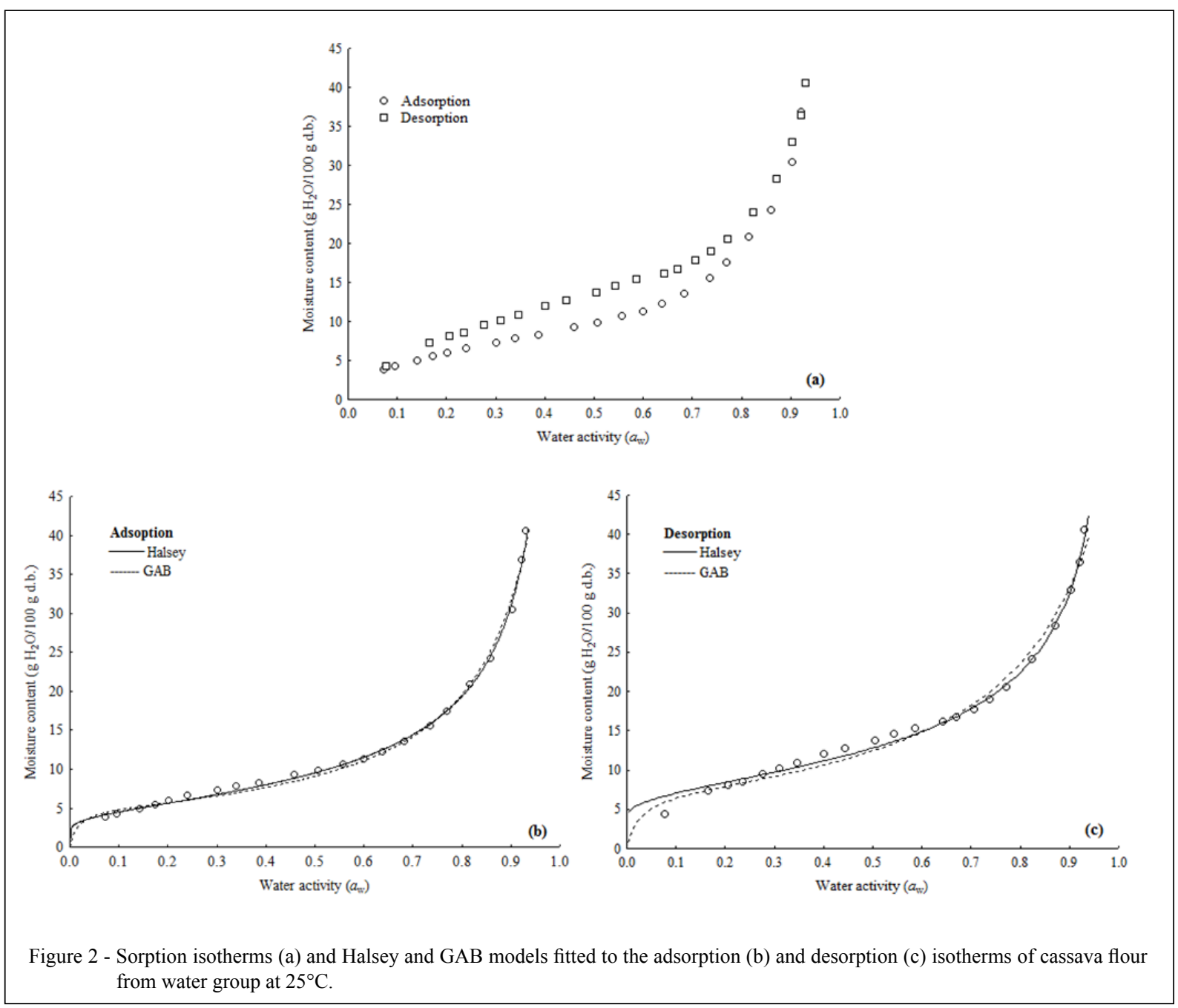

isotherm of ten hydrophobically modified cassava starches (COVA et al., 2010) and for tapioca flour (CHISTÉ et al., 2012).

For desorption, all tested models were also suitable for predicting the isotherm of both cassava flour with $\mathrm{R}^{2}$ ranging from 0.85 to 0.99 . For cassava flour from dry group, the lowest $\mathrm{P}$ values were observed for Handerson (4.8\%), GAB (6.9\%), Oswin $(8.2 \%)$ and BET $(9.9 \%)$ and only Oswin, Halsey, GAB and Smith models presented $\mathrm{P}$ values lower than $10 \%(4.9 \%, 5.6 \%, 6.7 \%$ and $7.7 \%$, respectively) for the water group (Table 3). All the tested models in this study have been reported to fit the moisture sorption behaviour of starch foods quite well (PENG et al., 2007; CHISTÉ et al., 2012).

The models of Oswin or GAB seems to be the best mathematical equations to perform the simultaneous prediction of the sorption isotherms of cassava flour from dry group (Figure $1 \mathrm{~b}$ and c), as well as the models of Halsey or GAB for cassava flour from water group (Figure $2 b$ and $c$ ). Thus, it is strong recommend the use of $\mathrm{GAB}$ equation to predict efficiently the sorption isotherms (adsorption and desorption) for cassava flour from dry and water groups at the entire range of tested $\mathrm{a}_{\mathrm{w}}$.

\section{CONCLUSION}

The hygroscopic behaviour of cassava flour from dry and water groups at $25^{\circ} \mathrm{C}$ showed that both flour presented type II isotherms and a type-H3 hysteresis loop between adsorption and desorption isotherms. According to the adsorption isotherms, the moisture content of both cassava flour should not be higher than $11.3 \%$ to ensure the theoretical microbiological stability of the products 
Table 3 - Parameters of mathematical modelling of sorption isotherms of cassava flour from dry and water groups at $25^{\circ} \mathrm{C}$.

\begin{tabular}{|c|c|c|c|c|c|c|c|}
\hline & \multirow{2}{*}{$\begin{array}{l}\text { Mathematical } \\
\text { models }\end{array}$} & \multicolumn{3}{|c|}{-------------Cassava flour from dry group-------------- } & \multicolumn{3}{|c|}{-----------Cassava flour from water group--------- } \\
\hline & & Equation parameters & $\mathrm{R}^{2}$ & $\mathrm{P}(\%)$ & Equation parameters & $\mathrm{R}^{2}$ & $\mathrm{P}(\%)$ \\
\hline \multirow{8}{*}{ Adsorption } & Halsey & $a=36.06 ; b=1.76$ & 0.99 & 5.6 & $a=25.65 ; b=1.60$ & 0.99 & 3.4 \\
\hline & Handerson & $\mathrm{a}=0.05 ; \mathrm{b}=1.14$ & 0.96 & 17.8 & $\mathrm{a}=0.07 ; \mathrm{b}=1.01$ & 0.95 & 24.6 \\
\hline & Kuhn & $\mathrm{a}=2.10 ; \mathrm{b}=5.93$ & 0.94 & 21.6 & $\mathrm{a}=2.61 ; \mathrm{b}=5.36$ & 0.98 & 13.9 \\
\hline & Mizrahi & $a=-6.79 ; b=-4.68$ & 0.94 & 22.8 & $a=-6.42 ; b=-3.79$ & 0.98 & 15.2 \\
\hline & Oswin & $\mathrm{a}=9.62 ; \mathrm{b}=0.48$ & 0.99 & 4.5 & $\mathrm{a}=9.73 ; \mathrm{b}=0.53$ & 0.99 & 11.1 \\
\hline & Smith & $\mathrm{a}=2.21 ; \mathrm{b}=10.96$ & 0.98 & 8.4 & $a=1.71 ; b=12.48$ & 0.96 & 15.4 \\
\hline & BET & $\mathrm{m}_{\mathrm{o}}=4.07 ; \mathrm{c}=24,146.07 ; \mathrm{n}=19.81$ & 0.97 & 11.7 & $\mathrm{~m}_{\mathrm{o}}=4.17 ; \mathrm{c}=3,699.70 ; \mathrm{n}=23.37$ & 0.98 & 9.6 \\
\hline & GAB & $\mathrm{m}_{\mathrm{o}}=5.06 ; \mathrm{c}=31.61 ; \mathrm{k}=0.91$ & 0.99 & 5.7 & $\mathrm{~m}_{\mathrm{o}}=4.90 ; \mathrm{c}=70.86 ; \mathrm{k}=0.94$ & 0.99 & 5.1 \\
\hline \multirow{8}{*}{ Desorption } & Halsey & $\mathrm{a}=230.06 ; \mathrm{b}=2.26$ & 0.97 & 14.9 & $\mathrm{a}=118.06 ; \mathrm{b}=2.02$ & 0.99 & 5.6 \\
\hline & Handerson & $\mathrm{a}=0.01 ; \mathrm{b}=1.57$ & 0.99 & 4.8 & $\mathrm{a}=0.02 ; \mathrm{b}=1.37$ & 0.96 & 12.8 \\
\hline & Kuhn & $a=1.95 ; b=9.65$ & 0.86 & 30.1 & $\mathrm{a}=2.40 ; \mathrm{b}=8.96$ & 0.95 & 17.2 \\
\hline & Mizrahi & $a=-10.46 ; b=-8.50$ & 0.85 & 30.9 & $a=-9.97 ; b=-7.55$ & 0.94 & 17.9 \\
\hline & Oswin & $\mathrm{a}=13.50 ; \mathrm{b}=0.37$ & 0.99 & 8.2 & $\mathrm{a}=13.10 ; \mathrm{b}=0.41$ & 0.99 & 4.9 \\
\hline & Smith & $a=5.44 ; b=10.93$ & 0.98 & 10.7 & $\mathrm{a}=4.67 ; \mathrm{b}=12.05$ & 0.98 & 7.7 \\
\hline & BET & $\mathrm{m}_{\mathrm{o}}=6.86 ; \mathrm{c}=23,07 ; \mathrm{n}=9.48$ & 0.96 & 9.9 & $\mathrm{~m}_{\mathrm{o}}=5.78 ; \mathrm{c}=9,428.90 ; \mathrm{n}=13.84$ & 0.96 & 12.1 \\
\hline & GAB & $\mathrm{m}_{\mathrm{o}}=9.00 ; \mathrm{c}=12.86 ; \mathrm{k}=0.79$ & 0.98 & 6.9 & $\mathrm{~m}_{\mathrm{o}}=7.22 ; \mathrm{c}=44.17 ; \mathrm{k}=0.87$ & 0.99 & 6.7 \\
\hline
\end{tabular}

The $\mathrm{a}_{\mathrm{w}}$ range in adsorption was $0.07-0.93$ and $0.93-0.08$ for desorption; $\mathrm{R}^{2}=$ coefficient of determination; $\mathrm{P}=$ mean relative deviation modulus.

during storage at $25^{\circ} \mathrm{C}$. Finally, GAB equation can be highlighted to be able to predict the sorption isotherms for both cassava flour.

\section{ACKNOWLEDGEMENTS}

The authors thank Conselho Nacional de Desenvolvimento Científico e Tecnológico (CNPq) and Fundação de Amparo à Pesquisa do Estado do Pará (FAPESPA) for the financial support.

\section{REFERENCES}

AOAC (ASSOCIATION OF OFFICIAL ANALYTICAL CHEMISTS). Official methods of analysis of the AOAC international. 16.ed. 3.Rev. Washington, 1997. 1141p.

CAURIE, M. Hysteresis phenomenon in foods. International Journal of Food Science \& Technology, v.42, n.1, p.45-49, 2007. Available from: <http://onlinelibrary.wiley.com/doi/10.1111/ j.1365-2621.2006.01203.x/pdf>. Accessed: Feb. 28, 2014. doi: 10.1111/j.1365-2621.2006.01203.x.

CHIRIFE, J.; IGLESIAS, H.A. Equations for fitting water sorption isotherms of foods: Part 1 - A review. International Journal of Food Science \& Technology, v.13, n.3, p.159174, 1978. Available from: <http://onlinelibrary.wiley.com/ doi/10.1111/j.1365-2621.1978.tb00792.x/pdf $>$. Accessed: Feb. 28, 2014. doi: 10.1111/j.1365-2621.1978.tb00792.x.

CHISTÉ, R.C.; COHEN, K.O. Physicochemical characterization of cassava flour from water group traded in the city of Belém, PA. Revista Brasileira de Tecnologia Agroindustrial, v.4, n.1, p.91-
99, 2010. Available from: <http://revistas.utfpr.edu.br/pg/index. $\mathrm{php} / \mathrm{rbta} /$ article/viewFile/452/500>. Accessed: Feb. 28, 2014. doi: 10.3895/S1981-36862010000100010.

CHISTÉ, R.C.; COHEN, K.O. Influence of fermentation on the quality of fermented cassava flour. Acta Amazonica, v.41, n.2, p.279-284, 2011. Available from: <http://www.scielo.br/pdf/aa/ v41n2/v41n2a13.pdf>. Accessed: Jun. 6, 2012. doi: 10.1590/ S0044-59672011000200013.

CHISTÉ, R.C. et al. Study of physical-chemical and microbiological properties when processing cassava flour from the water group. Ciência e Tecnologia de Alimentos, v.27, n.2, p.265-269, 2007. Available from: <http://www.scielo.br/pdf/cta/v27n2/08.pdf $>$. Accessed: Jun. 6, 2012. doi: 10.1590/S0101-20612007000200009.

CHISTÉ, R.C. et al. Quality of cassava flour from a dry group. Ciência e Tecnologia de Alimentos, v.26, n.4, p.861-864, 2006. Available from: <http://www.scielo.br/pdf/cta/v26n4/22.pdf $>$. Accessed: Jun. 6, 2012. doi: 10.1590/S0101-20612006000400023.

CHISTÉ, R.C. et al. Sorption isotherms of tapioca flour. International Journal of Food Science \& Technology, v.47, n.4, p.870-874, 2012. Available from: <http://onlinelibrary.wiley.com/ doi/10.1111/j.1365-2621.2011.02900.x/pdf>. Accessed: Mar. 21, 2012. doi: 10.1111/j.1365-2621.2011.02900.x.

COVA, A. et al. The effect of hydrophobic modifications on the adsorption isotherms of cassava starch. Carbohydrate Polymers, v.81, n.3, p.660-667, 2010. Available from: <http:// www.sciencedirect.com/science/article/pii/S0144861710001980>. Accessed: Feb. 28, 2014. doi: 10.1016/j.carbpol.2010.03.028.

FIGUEIRA, G.M. et al. Evaluation of desorption isotherms, drying rates and inulin concentration of chicory roots (Cichorium 
intybus L.) with and without enzymatic inactivation. Journal of Food Engineering, v.63, n.3, p.273-280, 2004. Available from: <http://www.sciencedirect.com/science/article/pii/ S0260877403003091>. Accessed: Feb. 28, 2014. doi: 10.1016/j. jfoodeng.2003.06.001.

KULCHAN, R. et al. Shelf life prediction of packaged cassavaflour-based baked product by using empirical models and activation energy for water vapour permeability of polyolefin films. Journal of Food Engineering, v.100, n.3, p.461-467, 2010. Available from: $<$ http://www.sciencedirect.com/science/article/pii/ S026087741000227X>. Accessed: Feb. 28, 2014. doi: 10.1016/j. jfoodeng.2010.04.031.

MAPA. Instrução normativa no52, de 7 de novembro de 2011 . Regulamento técnico da farinha de mandioca. Diário Oficial da União, 08 nov. 2011, Seção 1, 2011. Available from: $<$ http://www.agricultura.gov.br/legislacao/sislegis $>$. Acessed: Jul. 22, 2014.

MAROULIS, Z.B. et al. Application of the GAB model to the sorption isotherms for dried fruits. Journal of Food Engineering, v.7, n.1, p.63-70, 1988. Available from: $<$ http://www.sciencedirect. com/science/article/pii/0260877488900696>. Accessed: Oct. 21 , 2012. doi: 10.1016/0260-8774(88)90069-6

MISHRA, S.; RAI, T. Morphology and functional properties of corn, potato and tapioca starches. Food Hydrocolloids, v.20, n.5, 557-566, 2006. Available from: <http://www.sciencedirect.com/ science/article/pii/S0268005X0500010X $>$. Accessed: Feb. 28, 2014. doi: 10.1016/j.foodhyd.2005.01.001.

PENG, G. et al. Modeling of water sorption isotherm for corn starch. Journal of Food Engineering, v.80, n.2, p.562-567, 2007. Available from: <http://www.sciencedirect.com/science/
article/pii/S0260877406004778>. Accessed: Oct. 18, 2012. doi: 10.1016/j.jfoodeng. 2006.04.063.

PERDOMO, J. et al. Glass transition temperatures and water sorption isotherms of cassava starch. Carbohydrate Polymers, v.76, n.2, p.305-313, 2009. Available from: < http://www. sciencedirect.com/science/article/pii/S0144861708004955>. Accessed: Feb. 28, 2014. doi: 10.1016/j.carbpol.2008.10.023.

RAO, K.J. et al. Moisture sorption characteristics of chhana podo at $5^{\circ} \mathrm{C}$ and $35^{\circ} \mathrm{C}$. Journal of Food Engineering, v.76, n.3, p.453-459, 2006. Available from: $<$ http://www.sciencedirect.com/ science/article/pii/S0260877405003250>. Accessed: Feb. 28 , 2014. doi: 10.1016/j.jfoodeng.2005.04.048.

SCOTT, W.J. Water relations of food spoilage microorganisms Advances in Food Research, v.7, p.83-127, 1957.

SING, K.S.W. Reporting physisorption data for gas/solid systems with special references to the determination of surface area and porosity. Pure and Applied Chemistry, v.54, n.11, p.2211-2218, 1982. Available from: <http://pac.iupac.org/publications/pac/ pdf/1982/pdf/5411x2201.pdf>. Accessed: Jul. 22, 2014.

SOUZA, T.C.L. et al. A rapid method to obtaining moisture sorption isotherms of a starchy product. Starch/Stärke, v.65, n.56, p.433-436, 2013. Available from: <http://onlinelibrary.wiley. com/doi/10.1002/star.201200184/pdf>. Accessed: Apr. 30, 2013. doi: $10.1002 /$ star.201200184.

YANNIOTIS, S.; BLAHOVEC, J. Model analysis of sorption isotherms. LWT - Food Science and Technology, v.42, n.10, p.1688-1695, 2009. Available from: <http://www.sciencedirect. com/science/article/pii/S0023643809001467>. Accessed: Set. 18, 2012. doi: 10.1016/j.lwt.2009.05.010. 